\title{
Evaluation of flexural properties and dynamic mechanical analysis of glass fiber-reinforced polyamide resin
}

\section{Purpose}

The aim of this study was to evaluate flexural strength, elastic modulus and dynamic mechanical analysis (DMA) of heat-polymerized polymethyl methacrylate resin, polyamide resin and glass fiber-reinforced polyamide resin.

\section{Materials and Methods}

Three groups were determined according to denture base materials as polymethyl methacrylate resin $(\mathrm{H})$, polyamide resin $(\mathrm{P})$ and glass fiber reinforced polyamide resin $(R)$. Sixteen specimens for each denture base material were prepared with dimensions of $64 \times 10 \times 3.3 \mathrm{~mm}$ for three-point bending test. Two specimens for each denture base material were prepared with dimensions of $30 \times 10 \times 3 \mathrm{~mm}$ for DMA. Polymethyl methacrylate and polyamide specimens were prepared according to the manufacturer's recommendations. The silane was applied to glass fibers ( 4.5 $\mathrm{mm}$ length) $2 \%$ by weight of the polyamide resin, they were placed in polyamide resin cartilages and injected to the mold. The thermal aging procedure was applied to half of specimens of each material $(n=8)$. Flexural strength and elastic modulus of the specimens were determined by three-point bending test at a speed of $5 \mathrm{~mm} /$ min. DMA was performed to 1 specimen from each group to evaluate viscoelastic properties. Data were analyzed with one-way ANOVA, Tukey and Paired t tests.

\section{Results}

A statistically significant difference was found in flexural strength and elastic modulus values of denture base materials $(p=0.00)$. The highest flexural strength and elastic modulus values were observed in polymethyl methacrylate group. There was no significant difference between polyamide and glass-fiber reinforced polyamide groups $(p=0.497)$. No significant difference was determined in all threedenture base materials before and after aging procedure.

\section{Conclusion}

The reinforcement with glass-fibers did not affect the flexural strength and elastic modulus of polyamide resin.

Keywords: Polyamide resin, flexural strength, DMA, strengthening, glass fiber

\section{Introduction}

Polymethyl methacrylate (PMMA) resins have been widely used in removable prosthetic restorations. They have some advantages such as easy manipulation, aesthetic appearance, low water absorption and solubility, compatibility with oral tissues and polishability $(1,2)$. However, polymerization shrinkage, low impact strength, low fatigue resistance and residual monomer content are significant disadvantages $(3,4)$. Metal substructures, which are used to increase durability of the PMMA, may cause allergenic reactions as a result of corrosion. Also, the metal clasps affect aesthetic appearance (5). Different methods have been developed to overcome these disadvantages such as; adding filling materials to rein-

\author{
Senem Ünver ${ }^{1} \mathbb{D}$, \\ Arzu Zeynep Yıldırım ${ }^{1}$
}

Presented at: The 25th International Scientific Congress and Exhibition of Izmir Dental Association, Izmir, Turkey, Nov 2018.

ORCID IDs of the authors: S.Ü. 0000-0001-5565-1167; A.Z.Y. 0000-0002-9332-8982

'Department of Prosthodontics, Faculty of Dentistry, Gazi University, Ankara, Turkey Corresponding Author: Senem Ünver E-mail: dtsenemuysal@hotmail.com

Received: 31 October 2020 Revised: 4 January 2021 Accepted: 9 February 2021 
force of resins, chemical modifications of polymer with copolymerization and cross-linking of resin materials, producing new materials with different polymerization technics (6-8). Strengthening materials such as glass fiber, aramid fiber, nanodiamond powder, zirconium oxide, aluminum oxide, halloysite nanotubes, metal wires and carbon nanotubes can be added to denture base in order to increase fatigue resistance and fracture resistance of the prosthetic base materials (9-17). However, the most effective reinforcement is yet to be determined (18). The glass fiber-reinforcement have showed promising results in previous studies $(9,19,20)$.

Injection molding technique has been developed to improve the physical properties of denture base resins (21). Injection molding technique decreases polymerization shrinkage and improve dimensional stability of the resins compared to compression-molding technique (22-24). Polyamide resin is one of the materials prepared with this technique and it can be used safely in patients who are allergic to metal or resin monomers (25). Polyamide resin has higher elasticity than PMMA, and it can be preferred in the presence of tissue undercuts which cannot be corrected by surgical operations $(26,27)$. However, the flexibility of denture base may lead to permanent deformation in the prosthesis during mastication and, resorption of underlying bone structure due to the vertical stress that occurs from deformation (17). Nakamura et al. (9) stated that flexible resins must be strengthened, and glass fiber can be used to increase flexural strength of polyamide.

The glass fiber, which was developed to reinforce the polyamide resin material, was used in this study. Its purpose was to evaluate flexural strength, elastic modulus and dynamic mechanical analysis of PMMA, polyamide resin and glass fiber-reinforced polyamide resin before and after thermocycling procedure. The first null hypothesis was that the glass fiber-reinforcement would affect the flexural properties of the polyamide resin and the second null hypothesis was that there would not be any difference between flexural strength values of denture base materials before and after thermocycling procedure.

\section{Materials and methods}

\section{Material selection}

One PMMA (Meliodent; Heraeus-Kulzer GmbH, Wehrheim, Germany) and one polyamide resin (Deflex; Nuxen SRL, Buenos Aires, Argentina) were selected. E-glass fibers (PA2(D); Şişecam, İstanbul, Turkey) were added to reinforce of polyamide resin. Three groups were determined according to denture base materials as PMMA $(H)$, polyamide resin $(P)$ and glass fiber reinforced polyamide resin (R).

\section{Fabrication of specimens}

Forty-eight flexural strength test specimens were prepared in accordance with ISO 20795-1:2013 with dimensions of $64 \times 10 \times 3.3 \mathrm{~mm}$ (16 specimens for each denture base material) (28). For dynamic mechanical analysis, 2 specimens for each denture base material were prepared with dimensions of $30 \times 10 \times 3 \mathrm{~mm}$. For dimensions standardization, metal molds were fabricated. Wax specimens were produced by using metal molds, they were embedded in the cast molds and removed. Separating agent was applied on the cast molds and the molds were left to dry. For PMMA specimens, the powder and liquid (35 gr: $14 \mathrm{ml}$, powder: liquid) were mixed with a spatula and then the resin was inserted in the cast molds. The cast molds were placed in boiling water and the heat source were switched off for $15 \mathrm{~min}$. Then the specimens were polymerized in boiling water for 20 min according to the manufacturer's recommendation (29). The cast molds were allowed to cool at room temperature. For the polyamide resin specimens, the polyamide resins in the cartridges were heated to a temperature of $280^{\circ} \mathrm{C}$ for 15 minutes and were injected to the cast molds with a 6-bar for 30 seconds. E-glass fibers with a diameter of $11 \mu$, which were cut into length of $4.5 \mathrm{~mm}$ by manufacturer, were selected. For each specimen, glass fibers were $2 \%$ by weight of the polyamide resin. The E-glass fibers were weighed and the silane (Ultradent Silane; Ultradent Products Inc., South Jordan, USA) was applied to the E-glass fibers. The silanized E-glass fibers were placed in the polyamide resin cartridges and mixed thoroughly. The cartridges were heated to a temperature of $280^{\circ} \mathrm{C}$ for 15 minutes and the polyamide resins were injected to the cast molds with a bar injection pressure for 30 seconds. All of the specimens were straightened by using a diamond burr and were smoothed by using 600-grit silicon carbide paper. After polishing procedure, the dimensions of specimens were measured with digital micrometer. The specimens were stored in water at $37^{\circ} \mathrm{C}$ for 24 hours before thermocycling procedure. The artificial aging procedure was applied to half of specimens of each material and 2 subgroups were determined. $(n=8)$.

\section{Thermocycling procedure}

The artificial aging procedure was performed on half of specimens of each material with the thermal cycling device (SD Mechatronik Thermocycler; SD Mechatronik GMBH, Feldkirchen-Westerham, Germany) for 5000 cycles from $5^{\circ} \mathrm{C}$ to $50^{\circ} \mathrm{C}$ temperatures with 60 seconds waiting time.

\section{Flexural strength test}

The specimens were placed in a universal test machine (Lloyd LRX; Lloyd Instruments Ltd., Fareham, Hampshire, UK) with a $50 \mathrm{~mm}$ interface and subjected to three-point bending test at a speed of $5 \mathrm{~mm} / \mathrm{min}$ until fracture or maximum deflection occurred to determine of the flexural strength $(\mathrm{MPa})$ and the elastic modulus (GPa) of the specimens. The flexural strength was calculated using the formula $3 \mathrm{FI} / 2 \mathrm{bh}^{2}$, where $F$ is the maximum fracture load $(N), I$ is the distance between the supports $(\mathrm{mm}), \mathrm{b}$ is the width of the specimen $(\mathrm{mm}), \mathrm{h}$ is the height of the specimen $(\mathrm{mm})$. The elastic modulus (GPa) was calculated according to the formula $\mathrm{F} 1_{1} 1^{3}$ $/ 4 \mathrm{bh}^{3} \mathrm{~d}$, where $\mathrm{F} 1$ is the load at a point in the straight-line portion of the load/deflection graph $(\mathrm{N})$, I is the distance between the supports $(\mathrm{mm}), \mathrm{b}$ is the width of the specimen $(\mathrm{mm}), \mathrm{h}$ is the height of the specimen $(\mathrm{mm}), \mathrm{d}$ is the deflection $(\mathrm{mm})$ at load F1.

\section{Scanning electron microscope (SEM) examination}

One specimen of glass fiber reinforced polyamide was fractured in liquid nitrogen and the fractured surface was stud- 
ied under a scanning electron microscope (SEM) (JEOL JSM 6060LV, Noran Instruments, Japan) after gold sputtering to describe glass fiber distribution and fiber-resin connection.

\section{Dynamic Mechanical Analysis}

The dynamical mechanical analysis (DMA) was performed to evaluate viscoelastic properties of PMMA, polyamide resin and glass fiber reinforced polyamide resin materials. The temperature range of DMA (Q800; TA Instruments, New Castle, USA) was from $20^{\circ} \mathrm{C}$ to $200^{\circ} \mathrm{C}$ with $5^{\circ} \mathrm{C} / \mathrm{min}$ heat rate.

\section{Statistical analysis}

The mean flexural strength and elastic modulus values were calculated by using SPSS statistical software package program (SPSS version 24.0 software; SPSS, Chicago, IL, USA). Shapiro-Wilk test was performed to evaluate the normally distribution of the data and the data showed a normal distribution. Parametric tests were used. Data were analyzed by one-way ANOVA test to study the difference among the denture base materials $(P<0.05)$. Tukey test was applied for pairwise comparisons of the groups and paired t test was used to decide the effect of the thermocycling procedure on denture base materials. Level of significance was set at $P<0.05$.

\section{Results}

The mean values and standard deviations of flexural strength of denture base materials before and after aging procedure are listed in Table 1. Both before and after thermocycling procedure, the flexural strength values of $\mathrm{H}$ groups were significantly higher than $P$ and $R$ groups $(P=0.000)$ (Table 2$)$, however it was observed that there was no significant difference between $\mathrm{P}$ and $\mathrm{R}$ groups. The mean values and standard deviations of elastic modulus of denture base materials are shown in Table 3. The comparison of elastic modulus values of the denture materials was revealed that there was a significant difference between groups $(\mathrm{P}=0.000)$ (Table 4) and the $\mathrm{H}$ group had higher values than $\mathrm{P}$ and $\mathrm{R}$ groups.

The paired $t$ test, which used to evaluate the effect of artificial aging on flexural strength of denture base materials, revealed that there was no significant difference between denture materials before and after thermocycling (Group $\mathrm{H}$, $\mathrm{P}=0.049$; Group $\mathrm{P}, \mathrm{P}=0.554$; Group $\mathrm{R}, \mathrm{P}=0.922$ ). Similarly, the aging procedure did not effect of elastic modulus of denture base materials (Group H, P=0.549; Group P, P=0.267; Group $R, P=0.321$ ). During the flexural test, all of the PMMA specimens on $\mathrm{H}$ groups were fractured. Besides, none of the specimens of $\mathrm{P}$ and $\mathrm{R}$ groups were fractured and during the test but they detached from the supporting clamps. Therefore, flexural yield strength values of $P$ and $R$ groups were considered as flexural strength.

SEM images of the fractured surface of glass fiber reinforced polyamide specimen are shown in Figure 1 and Figure 2. The glass fibers were not distributed uniformly in polyamide resin and some fibers were bunched together in some areas (Figure 1). Cohesive type failure was detected between glass fiber and polyamide, and the hole of detached fiber was seen at x2000 magnification (Figure 2).

Storage modulus ( $\left.E^{\prime}\right)$ and tan delta of groups before and af- ter aging procedure are presented in Figure 3, Figure 4, Figure 5 and Figure 6 respectively. The glass transition temperatures for the PMMA, polyamide resin and glass fiber-reinforced polyamide resin were found $144.5^{\circ} \mathrm{C}, 134.26^{\circ} \mathrm{C}$ and $134.22^{\circ} \mathrm{C}$ respectively (Table 5 ). After thermocycling procedure, the glass transition temperature decreased for each denture base material. Both before and after thermocycling procedure the form of polyamide resin and glass fiber-reinforced polyamide resin specimens were distorted permanently (Figure 7).

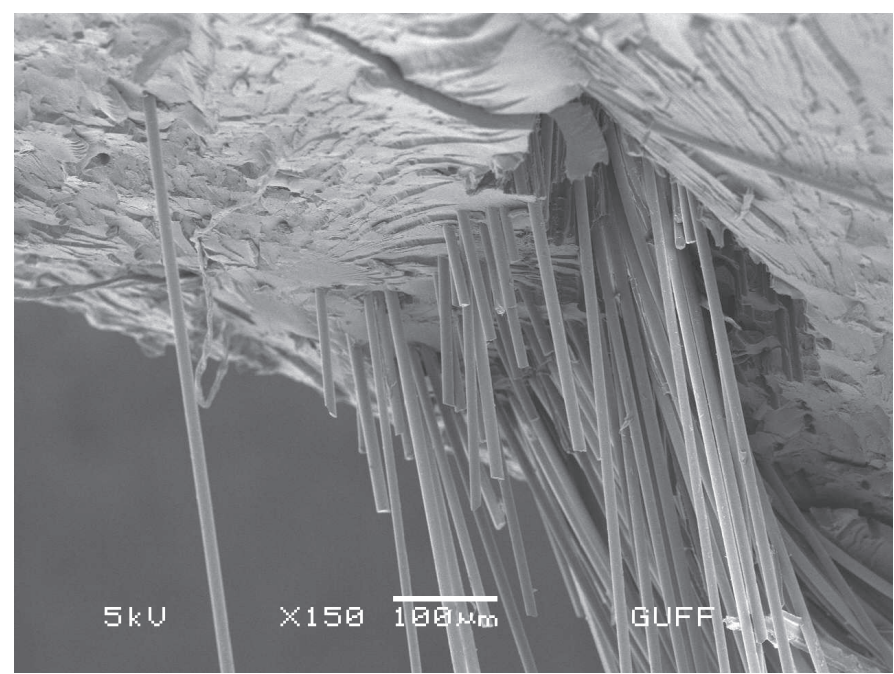

Figure 1. Fractured surface of glass fiber reinforced polyamide resin specimen under SEM (x150 magnification).

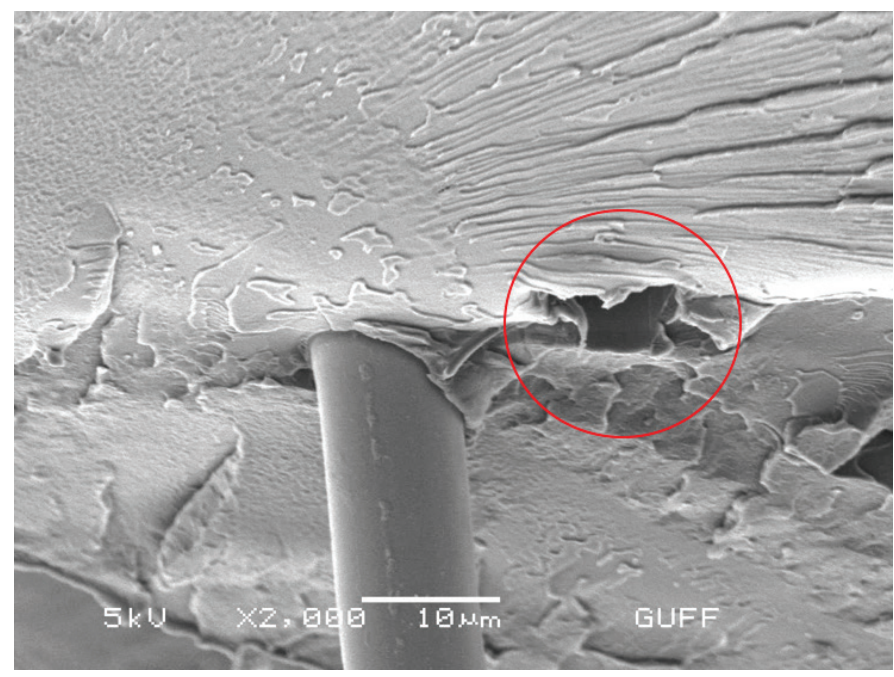

Figure 2. Fractured surface of glass fiber reinforced polyamide resin specimen under SEM (x2000 magnification).

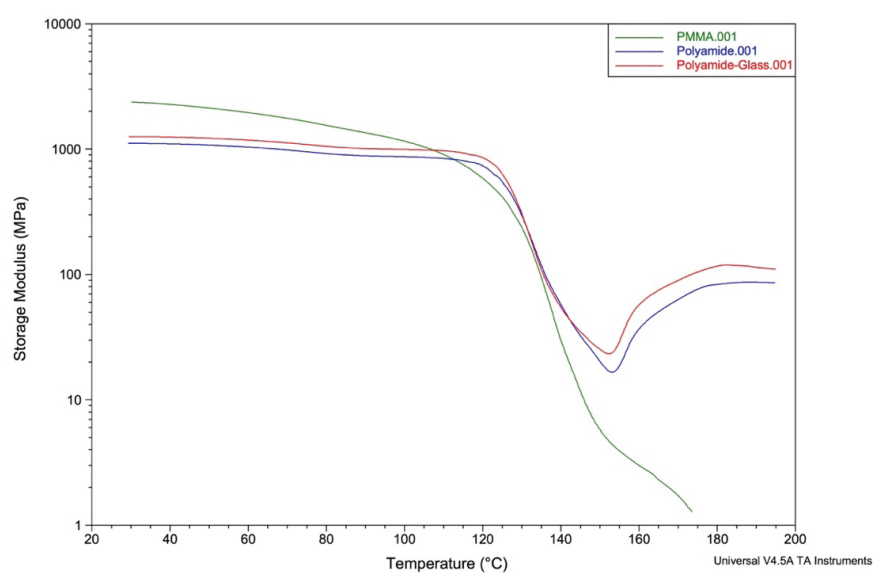

Figure 3. Storage modulus of the groups before aging procedure. 


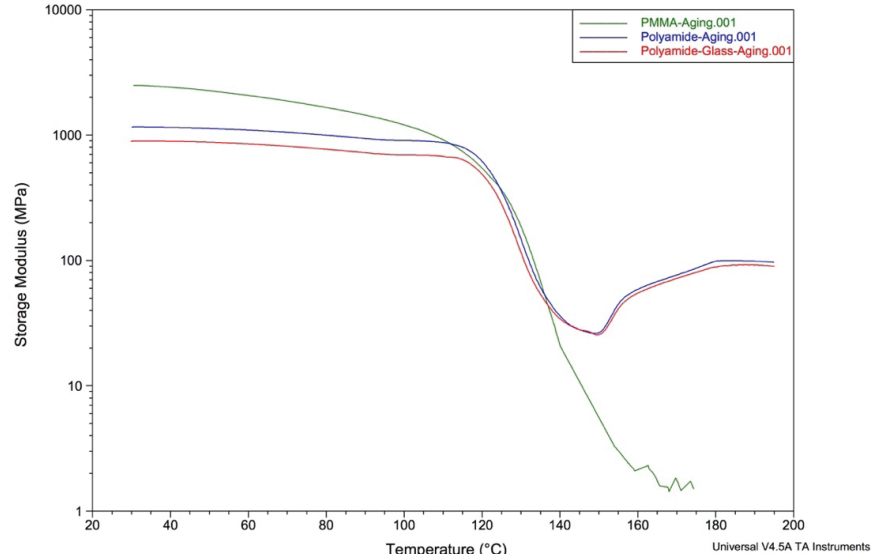

Figure 4. Storage modulus of the groups after aging procedure.

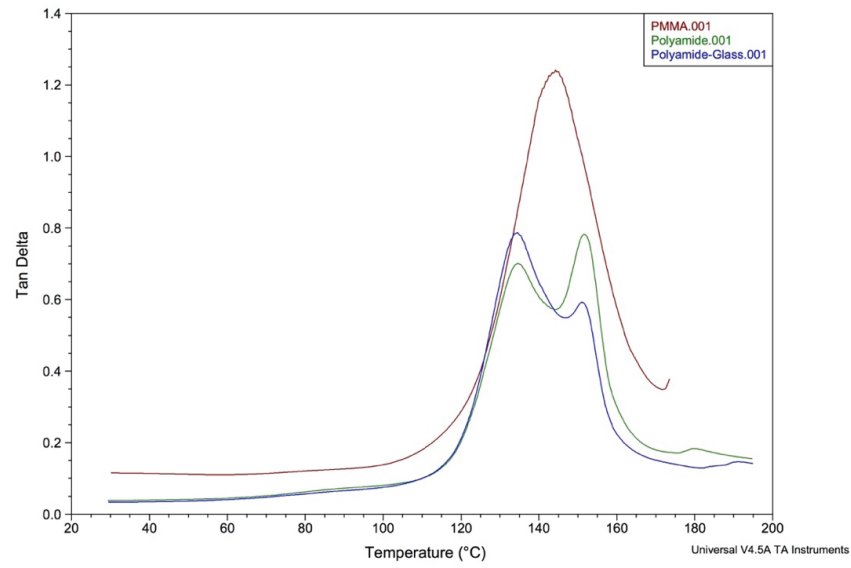

Figure 5. Tan delta of groups before aging procedure.

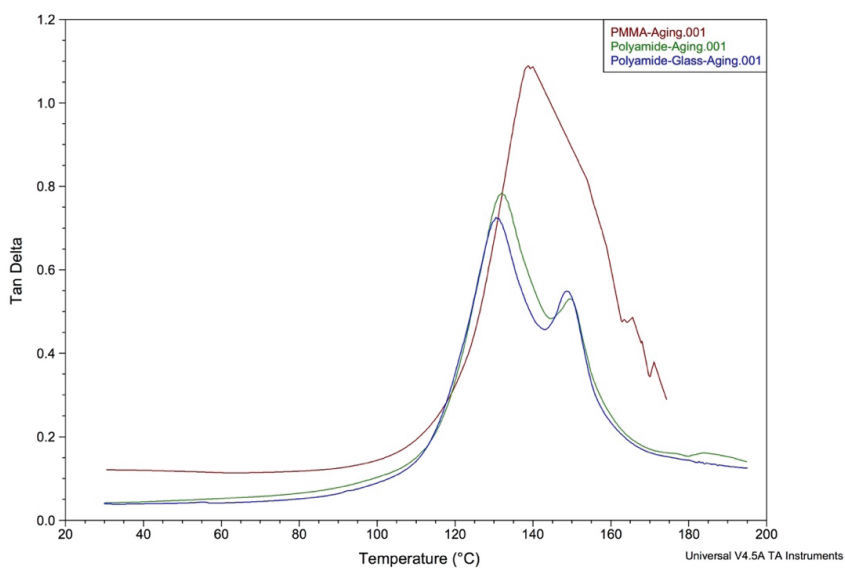

Figure 6. Tan delta of groups after aging procedure.

Before Aging

After Aging

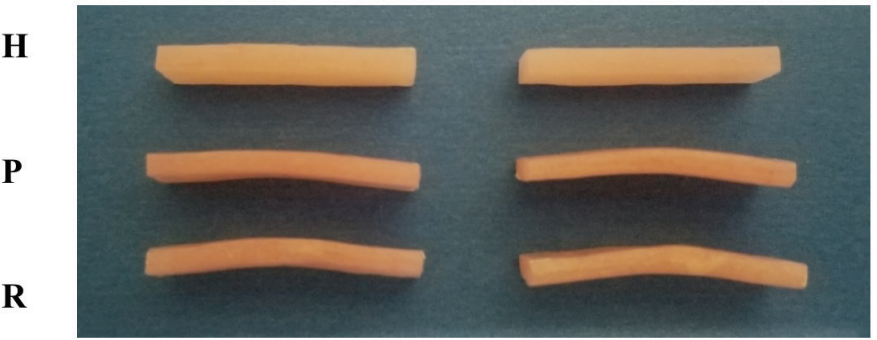

Figure 7. The specimens after DMA.
Table 1. Flexural strength values of the groups (MPa).

\begin{tabular}{|c|c|c|c|c|c|}
\hline \multirow{2}{*}{ Group } & \multicolumn{3}{|c|}{$\begin{array}{l}\text { Before } \\
\text { Aging }\end{array}$} & \multirow{2}{*}{$\begin{array}{c}\text { After } \\
\text { Aging } \\
\begin{array}{c}\text { Mean } \\
\pm S D\end{array}\end{array}$} & \multirow{2}{*}{$c p$} \\
\hline & & $\begin{array}{c}\text { Mean } \\
\pm \text { SD }\end{array}$ & & & \\
\hline H & & $\begin{array}{r}119.85 \\
\pm 15.65\end{array}$ & & $\begin{array}{c}118.9 \\
\pm 31.05\end{array}$ & $0.949^{* * *}$ \\
\hline $\mathbf{P}$ & & $\begin{array}{c}80.13 \\
\pm 12.74\end{array}$ & & $\begin{array}{c}75.3 \\
\pm 15.53\end{array}$ & $0.554^{* * *}$ \\
\hline \multirow[t]{2}{*}{$\mathbf{R}$} & & $\begin{array}{c}72.16 \\
\pm 13.12\end{array}$ & & $\begin{array}{l}71.73 \\
\pm 14.8\end{array}$ & $0.922^{* * *}$ \\
\hline & ${ }^{\mathrm{a}} \mathbf{p}$ & $0.000^{*}$ & & $0.000^{*}$ & \\
\hline Pairwise & H-P & $39.72^{* *}$ & H-P & $43.6^{* *}$ & \\
\hline $\begin{array}{l}\text { Comparisons; } \\
{ }^{\mathrm{b}} \mathbf{p}\end{array}$ & $\begin{array}{l}\text { H-R } \\
\text { P-R }\end{array}$ & $\begin{array}{c}47.69^{* *} \\
7.97\end{array}$ & $\begin{array}{l}\text { H-R } \\
\text { P-R }\end{array}$ & $\begin{array}{c}47.17^{* *} \\
3.56\end{array}$ & \\
\hline $\begin{array}{l}\text { (SD: Standard devi } \\
\text { P: Polyamide, R: Glc } \\
\text { Test*p }<0.001, \text { ' } T \text { K }\end{array}$ & $\begin{array}{l}n, H: H \\
\text { iber } r \\
\text { Test * }\end{array}$ & $\begin{array}{l}\text { t-polym } \\
\text { orced po } \\
0.05,{ }^{\circ}\end{array}$ & $\begin{array}{l}\text { dpoly } \\
\text { ide. } \\
\text { t Tes }\end{array}$ & $\begin{array}{l}\text { thyl meth } \\
\text { e way AN } \\
\left.{ }^{*} p<0.05\right) \text {. }\end{array}$ & $\begin{array}{l}\text { rylate, } \\
\text { VA }\end{array}$ \\
\hline
\end{tabular}

Table 2. One-way ANOVA analysis of flexural strength values of the groups before and after aging.

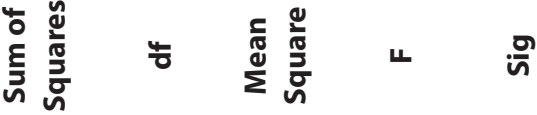

\begin{tabular}{lccccc}
\hline Before aging & & & & & \\
\hline Between Groups & 10441.958 & 2 & 5220.979 & 27.03 & 0.000 \\
\hline Within Groups & 4056.301 & 21 & 193.157 & & \\
\hline Total & 14498.258 & 23 & & & \\
\hline After aging & & & & & \\
\hline Between Groups & 11036.133 & 2 & 5518.067 & 11.621 & 0.000 \\
\hline Within Groups & 9971.596 & 21 & 474.838 & & \\
\hline Total & 21007.729 & 23 & & & \\
\hline
\end{tabular}

Table 3. Elastic modulus values of the groups (GPa).

\begin{tabular}{|c|c|c|c|c|c|}
\hline \multirow[t]{2}{*}{ Group } & \multicolumn{2}{|r|}{$\begin{array}{l}\text { Before } \\
\text { Aging }\end{array}$} & & $\begin{array}{l}\text { After } \\
\text { Aging }\end{array}$ & \multirow[t]{2}{*}{$c p$} \\
\hline & & Mean \pm SD & & Mean \pm SD & \\
\hline H & & $5.79 \pm 0.64$ & & $6.12 \pm 1.27$ & $0.549 * * *$ \\
\hline $\mathbf{P}$ & & $3.03 \pm 0.69$ & & $2.54 \pm 0.64$ & $0.266^{* * *}$ \\
\hline \multirow[t]{2}{*}{$\mathbf{R}$} & & $2.61 \pm 0.63$ & & $2.38 \pm 0.68$ & $0.319^{* * * *}$ \\
\hline & ${ }^{\mathrm{a}} \mathbf{p}$ & $0.000^{*}$ & & $0.000^{*}$ & \\
\hline Pairwise & H-P & $2.76^{* *}$ & H-P & $3.58^{* *}$ & \\
\hline \multirow{2}{*}{$\begin{array}{l}\text { Comparisons; } \\
{ }^{\mathrm{b} p}\end{array}$} & H-R & $3.18^{* *}$ & H-R & $3.74^{* * *}$ & \\
\hline & P-R & 4.21 & P-R & 0.16 & \\
\hline
\end{tabular}

(SD: Standard deviation, H: Heat-polymerized polymethyl methacrylate, $P$ : Polyamide, R: Glass fiber reinforced polyamide. ${ }^{a}$ One way ANOVA Test ${ }^{*} p<0.001,{ }^{b}$ Tukey Test ${ }^{* *} p<0.05$, 'Paired t Test ${ }^{* * *} p<0.05$ ). 
Table 4. One-way ANOVA analysis of elastic modulus values of the groups before and after aging.

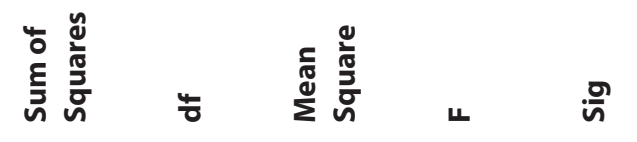

\begin{tabular}{|c|c|c|c|c|c|}
\hline \multicolumn{6}{|l|}{ Before aging } \\
\hline $\begin{array}{l}\text { Between } \\
\text { Groups }\end{array}$ & 47.656 & 2 & 23.828 & 55.745 & 0.000 \\
\hline Within Groups & 8.976 & 21 & 0.427 & & \\
\hline Total & 56.632 & 23 & & & \\
\hline \multicolumn{6}{|l|}{ After aging } \\
\hline $\begin{array}{l}\text { Between } \\
\text { Groups }\end{array}$ & 71.471 & 2 & 35.735 & 43.068 & 0.000 \\
\hline Within Groups & 17.424 & 21 & 0.83 & & \\
\hline Total & 88.895 & 23 & & & \\
\hline
\end{tabular}

Table 5. The glass transition temperatures of denture base materials before and after thermocycling procedure.

\begin{tabular}{lcc} 
Group & Before aging & After aging \\
\hline $\mathbf{H}$ & $144.53^{\circ} \mathrm{C}$ & $138.40^{\circ} \mathrm{C}$ \\
\hline $\mathbf{P}$ & $134.26^{\circ} \mathrm{C}$ & $132.26^{\circ} \mathrm{C}$ \\
\hline $\mathbf{R}$ & $134.22^{\circ} \mathrm{C}$ & $130.79^{\circ} \mathrm{C}$ \\
\hline
\end{tabular}

(H: Heat-polymerized polymethyl methacrylate, P: Polyamide, R: Glass fiber reinforced polyamide).

\section{Discussion}

This in vitro study demonstrated that the PMMA had higher flexural strength and elastic modulus values than the polyamide resin and glass fiber-reinforced polyamide resin. PMMA has been the most commonly used material for removable prosthodontics and polyamide is an alternative. The glass fiber, which were used in current study, has been developed for the reinforcement of polyamide material. The study was planned to determine the effect of this glass fiber on flexural properties of polyamide but, at the same time, the reinforced polyamide was compared with PMMA to decide whether it can replace the PMMA.The reinforcement of polyamide resin decreased the flexural strength and elastic modulus values but there was no statistically significant difference between them. So, these results were rejected the first null hypotheses of this study that the reinforcement would affect the flexural properties of polyamide resin material. Besides, the results confirmed the second null hypothesis that no significant difference would occur between flexural properties of denture base materials before and after thermocycling procedure.

Denture base materials are subjected to various forces such as compression and shear during mastication. Mechanical properties of denture base resins are often evaluated with flexural strength, modulus of elasticity and impact strength (17,30-33). These tests have been approved to imitate the natural forces acting on the prosthesis in oral environment (34). Flexural strength is the ability of a material to oppose the deformation under load and represents the highest stress encountered within the material at fracture moment (35). The denture base must have suitable rigidity to distribute the forces over the dental arch equally. Also, the flexibility of material is important for energy absorption in case of dropping the denture (8). According to ISO 20795$1: 2013$, flexural strength of denture base materials should be no less than $65 \mathrm{MPa}$ and flexural modulus no less than $2 \mathrm{GPa}$ (28). In the present study, both flexural strength and elastic modulus of each denture base materials were consistent with the specified ISO standards.

Even though PMMA is the most preferred denture base material, flexible resins were introduced by manufacturers as an alternative for constructing complete and partial removable dentures (36). Polyamide resin is usually indicated in patients who have allergy to methyl methacrylate monomer and retention problems due to certain degree of undercuts $(25,27)$. The major connector of the removable denture should have enough rigidity to distribution of the chewing force and low flexural modulus of denture base material is an important disadvantage $(6,7)$. Ucar et al. (8) reported that polyamide may be used for an alternative material for construction of complete dentures but not for removable partial dentures.

The denture base materials can be strengthened to prevent fractures which is a common complication. There are some studies that have evaluated the effect of reinforcement of PMMA with different materials, but the those on the reinforcement of polyamide resin are scarce $(7,9-17,33)$. In a previous study, the rigidity of dentures made of polyamide, polyester and conventional heat-polymerized PMMA were compared, and it was concluded that the polyamide, which has low elasticity, needed to be reinforced with metal frames (37). Soygun et al. (32) evaluated transverse strength of polyamide, PMMA and reinforced PMMA with different esthetic fibers Polyamide denture base material had higher transverse strength than PMMA and fiber-added groups. Also, no fracture occurred in polyamide specimens. They reported that the polyamide provided better energy absorption due to chemical structure properties. Sasaki et al. (17) compared the flexural strength of three different injection-molded thermoplastic denture base resins (polyamide, polyester, polycarbonate) with PMMA They reinforced the denture base materials with using glass fiber-reinforced composite and metal wire. It was stated that the glass fiber-reinforced composite was effective for polyamide and PMMA resins. In the present study, the glass fibers were used for reinforcement of polyamide resin. Glass fiber-reinforced polyamide specimens had lower values than polyamide specimens for both flexural strength and elastic modulus, but the results were not significant. The elastic stiffness of E-glass fibers does not change during heat treatments, but the mechanical strength of the material might be affected by the distribution of fibers inside the matrix $(38,39)$. When the reinforced specimens were prepared, the glass fibers were placed in the polyamide resin cartridges and the resin materials were injected with pressure to the mold. Consequently, the distribution of the fibers in the polyamide were uncontrolled. This result of the present study might be attributed to the non-homogeneous distribution of glass fibers in the material (Figure 1).

Liquid nitrogen was applied to the reinforced polyamide specimen to fracture owing to the fact that none of the reinforced polyamide specimens were fractured during flexural 
strength test. The SEM image of the fracture surface of the specimen was shown that the fibers stuck out from polyamide and the fibers showed resistance to fracture (Figure 2). Even though, silan application is an effective method to provide bonding between fiber and polymer matrix, the bonding depends on the mechanical retention caused by polymerization shrinkage of polymer and roughness of fibers $(40,41)$. Therefore, the adhesive type failure could have been observed between fibers and polyamide material.

Thermocycling procedure is an application for testing the long-term clinical use of dental materials and it is based on the temperature changes in the oral environment between $5^{\circ} \mathrm{C}-55^{\circ} \mathrm{C}$ due to the different types of nutrition (42). After aging procedure, the preservation of physical and mechanical properties of an ideal dental material is important but distance between the polymer chains may extend as a result of heat changes and the material may absorb water (42). So, water immersion causes water molecules to act as plasticizer in the polymer structure and unpolymerized PMMA can be dissolved by cyclic temperature changes (43). Takahashi et al. (44). stated that thermocycling significantly decreased flexural strength and elastic modulus of one polyamide (Valplast), but it increased same properties of the other polyamide (Lucitone FRS) This result could be explained with differences in physical properties and composition of different polyamides used in industry. In another study, the effect of thermocycling with different thermal cycles on polyamide and PMMA denture base resins was evaluated and it was concluded that there was no significant difference between flexural strengths of each group (42). In the present study, specimens were subjected to 5000 cycles to imitate the clinical function of 6 months approximately (45). In contrast to the literature, thermocycling procedure did not change the flexural strength and elastic modulus of groups significantly.

DMA, which is commonly studied to describe the mechanical behaviors of polymers and polymer composites, is a technique that oscillating force is applied to a specimen and analyzing the material's response to that force (46). $\mathrm{Tg}$ (glass transition temperature) value can be determined by DMA. The Tg represents a major transition for many polymers and physical properties of material change strongly as the material turns from a hard glassy to a rubbery state (47). In the present study, the glass transition temperatures of PMMA, polyamide resin and glass fiber-reinforced polyamide resin were found as $144.53^{\circ} \mathrm{C}, 134.26^{\circ} \mathrm{C}$ and $134.22^{\circ} \mathrm{C}$ respectively. The Tg values are high because both the PMMA and the polyamide are amorphous materials (30,48-50). Decrease in the glass transition temperatures of materials after thermocycling shows that the mechanical properties of denture base materials may be affected at mouth temperatures ranging between $5^{\circ} \mathrm{C}$ and $55^{\circ} \mathrm{C}$.

The clinical significances of the study are that the polyamide resin must be reinforced, and the temperature changes during clinical usage can be affect the flexural properties and durability of the denture base. There are some limitations in the present study. Only one reinforced material was tested for polyamide resin and only flexural strength, elastic modulus and DMA were tested. The properties of reinforced polyamide with different concentrations of E-glass fibers can be further evaluated. In vitro studies which investigate the different physicomechanical properties of polyamide resins reinforced with different materials would be helpful to provide case-specific solutions.

\section{Conclusion}

The PMMA had higher flexural strength and elastic modulus than polyamide resin and glass fiber-reinforced polyamide resin. Using the glass fiber for reinforcement of polyamide resin did not affect flexural strength and elastic modulus of the material. The thermocycling procedure did not change the flexural properties of the denture base materials. According to DMA, polyamide resins are more likely to deform than PMMA resins do.

Türkçe Özet: Cam Fiber ile Güçlendirilmiş Poliamid Rezinin Bükülme Özelliklerinin ve Dinamik Mekanik Analizinin Değerlendirilmesi. Amaç: Bu çalışmanın amacı, Isı ile polimerize polimetilmetakrilat rezin, poliamid rezin ve cam fiberle güçlendirilmiş poliamid rezin materyallerinin bükülme dayanımı, elastik modülüsü ve dinamik mekanik analizinin (DMA) değerlendirilmesidir. Gereç ve yöntem: Çalışmada, dental kaide materyallerine göre; polimetil metakrilat resin $(H)$, poliamid rezin $(P)$ ve cam fiberle güçlendirilmiş poliamid rezin $(R)$ olmak üzere 3 grup belirlendi. Her bir kaide materyalinden, 3 nokta bükülme testi için $64 \times 10 \times 3,3 \mathrm{~mm}$ boyutlarında 16 örnek, dinamik mekanik analiz için $30 \times 10 \times 3 \mathrm{~mm}$ boyutlarında 2 örnek hazırlandı. Polimetil metakrilat ve poliamid örnekler firma önerileri doğrultusunda hazırlandı. Poliamid rezinin ağırlığının \%2'si kadar $4.5 \mathrm{~mm}$ uzunluktaki cam fiberlere silan uygulandı, Cam fiberler poliamid rezin kartilaj içerisine yerleştirildi ve kalıplara enjekte edildi. Her bir materyalin örneklerinin yarısına termal yaşlandırma işlemi uygulandı $(n=8)$. Örneklerin bükülme dayanımı ve elastik modülüsü $5 \mathrm{~mm} / \mathrm{min}$ hızda üç nokta bükülme testi ile belirlendi. Viskoelastik özellikleri değerlendirmek için her gruptan 1 örneğe DMA yapıldı. Verilerin analizinde one-way ANOVA, Tukey ve Paired t testleri kullanıldı. Bulgular: Protez kaide materyallerinin bükülme dayanımı ve elastik modülüs değerleri arasında istatistiksel olarak anlamlı fark bulundu $(P<0.05)$. En yüksek bükülme dayanımı ve elastik modülüs değerleri polimetilmetakrilat grubunda gözlendi. Poliamid ve cam fiberle güçlendirilmiş poliamid grupları arasında istatistiksel olarak fark tespit edilmedi $(P=0.497)$. Her üç kaide materyalinde yaşlandırma işlemi öncesi ve sonrası değerlerde anlamlı fark görülmedi. Sonuç: Cam fiber poliamid rezinin bükülme dayanımını ve elastik modülüsünü değiştirmedi. Anahtar kelimeler: Poliamid rezin, bükülme dayanımı, dinamik mekanik analiz, güçlendirme, cam fiber.

Ethics Committee Approval: Not required.

Informed Consent: Not required.

Peer-review: Externally peer-reviewed.

Author contributions: SU, AZYB participated in designing the study. SU participated in generating the data for the study. SU participated in gathering the data for the study. SU participated in the analysis of the data. SU wrote the majority of the original draft of the paper. SU, AZYB participated in writing the paper. SU, AZYB have had access to all of the raw data of the study. SU, AZYB have reviewed the pertinent raw data on which the results and conclusions of this study are based. SU, AZYB have approved the final version of this paper. SU guarantees that all individuals who meet the Journal's authorship criteria are included as authors of this paper.

Conflict of Interest: The authors declared no conflict of interest.

Financial Disclosure: This study has been supported by Project of Scientific Investigation of Gazi University (project number: 03/2018-11). 


\section{References}

1. Uzun G, Hersek N, Tinçer T. Effect of five woven fiber reinforcements on the impact and transverse strength of a denture base resin. J Prosthet Dent 1999;81:616-20. [CrossRef]

2. Köroğlu, A, Özdemir T, Usanmaz A. Comparative study of the mechanical properties of fiber-reinforced denture base resin. $J$ App Polymer Sci 2009;113:716-20. [CrossRef]

3. Ali IL, Yunus N, Abu-Hassan MI. Hardness, Flexural Strength, and Flexural Modulus Comparisons of Three Differently Cured Denture Base Systems. J Prosthodont 2008;17:545-9. [CrossRef]

4. Athar Z, Juszczyk AS, Radford DR, Clark RK. Effect of curing cycles on the mechanical properties of heat cured acrylic resins. Eur J Prosthodont Restor Dent 2009;17:58-60.

5. Kanie T, Arikawa H, Fujii K, Ban S. Flexural properties of denture base polymers reinforced with a glass cloth-urethane polymer composite. Dent Mater 2004;20:709-16. [CrossRef]

6. Doğan OM, Bolayir G, Keskin S, Doğan A, Bek B. The evaluation of some flexural properties of a denture base resin reinforced with various aesthetic fibers. J Mater Sci Mater Med 2008;19:2343-9. [CrossRef]

7. Foo SH, Lindquist TJ, Aquilino SA, Schneider RL, Williamson DL, Boyer DB. Effect of polyaramid fiber reinforcement on the strength of 3 denture base polymethyl methacrylate resins. J Prosthodont 2001;10:148-53. [CrossRef]

8. Uçar Y, Akova T, Aysan I. Mechanical properties of polyamide versus different PMMA denture base materials. J Prosthodont 2012;21:173-6. [CrossRef]

9. Nagakura $M$, Tanimoto $Y$, Nishiyama N. Effect of fiber content on flexural properties of glass fiber-reinforced polyamide-6 prepared by injection molding. Dent Mater J 2017;36:415-21. [CrossRef]

10. Al-Harbi FA, Abdel-Halim MS, Gad MM, Fouda SM, Baba NZ, AlRumaih HS, Akhtar S. Effect of Nanodiamond Addition on Flexural Strength, Impact Strength, and Surface Roughness of PMMA Denture Base. J Prosthodont 2019;28:417-25. [CrossRef]

11. He X, Peng J, Peng T, Qian Z. A novel botryoidal aramid fiber reinforcement of a PMMA resin for a restorative biomaterial. Biomater Sci 2017;28:808-16. [CrossRef]

12. Gad MM, Al-Thobity AM, Rahoma A, Abualsaud R, Al-Harbi FA, Akhtar S. Reinforcement of PMMA Denture Base Material with a Mixture of ZrO2 Nanoparticles and Glass Fibers. Int J Dent 2019;2019:1-11.

13. Dhole PI, Shetty R, Huddar D, Sankeshwari B, Chopade S. Reinforcement of Aluminum Oxide Filler on the Flexural Strength of Different Types of Denture Base Resins: An In vitro Study. J Clin Diagn Res 2017;11:101-4. [CrossRef]

14. Abdallah RM. Evaluation of polymethyl methacrylate resin mechanical properties with incorporated halloysite nanotubes. J Adv Prosthodont 2016;8:167-71. [CrossRef]

15. Kumar V, Kumar L, Sehgal K, Datta K, Pal B. A Comparative Evaluation of Effect of Reinforced Autopolymerizing Resin on the Flexural Strength of Repaired Heatpolymerized Denture Base Resin before and after Thermocycling. J Int Soc Prev Community Dent 2017;7:99-106. [CrossRef]

16. Somkuwar S, Mishra SK, Agrawal B, Choure R. Comparison of the flexural strength of polymethyl methacrylate resin reinforced with multiwalled carbon nanotubes and processed by conventional water bath technique and microwave polymerization. J Indian Prosthodont Soc 2017;17:332-9. [CrossRef]

17. Sasaki H, Hamanaka I, Takahashi Y, Kawaguchi T. Effect of reinforcement on the flexural properties of injection-molded thermoplastic denture base resins. J Prosthodont 2017;26:3028. [CrossRef]

18. Takashi T, Gonda T, Mizuno Y, Fujinami Y, Maeda Y. Reinforcement in removable prosthodontics: a literature review. J Oral Rehabil 2017;44:133-43. [CrossRef]

19. Ladha K, Shah D. An In-Vitro Evaluation of the Flexural Strength of Heat-Polymerized Poly (Methyl Methacrylate) Denture Resin
Reinforced with Fibers. J Indian Prosthodont Soc 2011;11:21520. [CrossRef]

20. Gharehchahi J, Aghdaee NA, Kermani N. Evaluation of FRC reinforcing on flexural strength of acrylic resin denture bases. $\mathrm{N}$ Y State Dental J 2010;76:40-3.

21. Ganzarolli SM, Mello JAN, Shinkai RS, et al. Internal adaptation and some physical properties of methacrylate-based denture base resins polymerized by different techniques. J Biomed Mater Res Part B: App Biomater 2007;82:169-73. [CrossRef]

22. Anderson GC, Schulte JK, Arnold TG: Dimensional stability of injection and conventional processing of denture base acrylic resin. J Prosthet Dent 1988;60:394-8. [CrossRef]

23. Strohaver RA. Comparison of changes in vertical dimension between compression and injection molded complete dentures. J Prosthet Dent 1989;62:716-8. [CrossRef]

24. Huggett R, Zissis A, Harrison A, et al: Dimensional accuracy and stability of acrylic resin denture bases. J Prosthet Dent 1992;68:634-40. [CrossRef]

25. Stafford GD, Huggett R, MacGregor AR, Graham J. The use of nylon as a denture-base material. J Dent 1986;14:18-22. [CrossRef]

26. Hargreaves AS. Nylon as a denture-base material. Dent Pract Dent Rec 1971;22:122-8.

27. MacGregor AR, Graham J, Stafford GD, Huggett R. Recent experiences with denture polymers. J Dent 1984;12:14657. [CrossRef]

28. International Standards Organization. Dentistry-Base polymersPart 1: Denture base polymers. ISO 20795-1. International Standards Organization, Geneva, Switzerland; 2013.

29. https://www.kulzer.com/media/webmedia_local/downloads new/meliodent_1/medliodent_hc/GBA_MelioDent_HC_ Regio_INT.pdf

30. Kürkçüoğlu I, Köroğlu A, Özkır SE, Özdemir T. A comparative study of polyamide and PMMA denture base biomaterials: I. Thermal, mechanical, and dynamic mechanical properties. Int J Polym Mater 2012;61:768-77. [CrossRef]

31. Kohli S, Bhaita S. Flexural properties of polyamide versus injectionmolded polymethylmethacrylate denture base materials. Eur J Prosthodont 2013;1:56-60. [CrossRef]

32. Soygun K, Bolayir G, Boztug A. Mechanical and thermal properties of polyamide versus reinforced PMMA denture base materials. J Adv Prosthodont 2013;5:153-60. [CrossRef]

33. Demir H, Gorler O, Dogan A, Ozden S. The assessment of impact properties of a denture base polymer reinforced with various fibers. Int J Acad Res 2017;9:15-9. [CrossRef]

34. McCabe JF, Walls AWG. Applied dental materials. 9th Ed., Copenhagen: Blackwell Munksgaard 2008, p.4-31.

35. Chitchumnong P, Brooks SC, Stafford GD. Comparison of three and four-point flexural strength testing of denture-base polymers. Dent Mater 1989;5:2-5. [CrossRef]

36. Goiato MC, Santos DM, Haddad MF, Pesqueira AA. Effect of accelerated aging on the microhardness and color stability of flexible resins for dentures. Braz Oral Res 2010;24:1149. [CrossRef]

37. Wadachi J, Sato M, Igarashi Y. Evaluation of the rigidity of dentures made of injection-molded materials. Dent Mater J 2013;32:508-11. [CrossRef]

38. Feih S, Manatpon K, Mathys Z, Gibson AG, Mouritz AP. Strength degradation of glass fibers at high temperatures J Mater Sci 2009;44:392-400.

39. Doğan OM, Bolayir G, Keskin S, Doğan A, Bek B, Boztuğ A. The effect of esthetic fibers on impact resistance of a conventional heat-cured denture base resin. Dent Mater J 2007;26:232-9. [CrossRef]

40. Karacaer O, Polat TN, Tezvergil A, Lassila LV, Vallittu PK. The effect of length and concentration of glass fibers on the mechanical properties of an injection-and a compression molded denture base polymer. J Prosthet Dent 2003;90:385-93. [CrossRef]

41. Kanie T, Fujii K, Arikawa H, Inoue K. Flexural properties and impact strength of denture base polymer reinforced with woven glass fibers. Dent Mater 2000;16:150-8. [CrossRef] 
42. Aydoğan Ayaz E, Bağış B, Turgut S. Effects of thermal cycling on surface roughness, hardness and flexural strength of polymethylmethacrylate and polyamide denture base resins. J Appl Biomater Funct Mater 2015;13:280-6.

43. Göhring TN, Gallo L, Lüthy H. Effect of water storage, thermocycling, the incorporation and site of placement of glass-fibers on the flexural strength of veneering composite. Dent Mater 2005;21:761-72. [CrossRef]

44. Takahashi Y, Hamanaka I, Shimizu H. Effect of thermal shock on mechanical properties of injection-molded thermoplastic denture base resins. Acta Odontol Scand 2012;70:297-302. [CrossRef]

45. Xie $C$, Han $Y$, Zhao $X Y$, Wang ZY, He HM. Microtensile bond strength of one- and two-step self-etching adhesives on sclerotic dentin: the effects of thermocycling. Oper Dent 2010;35:547-55. [CrossRef]

46. Menard KP. Dynamic Mechanical Analysis: A Practical Introduction. 2nd Ed., Boca Raton: CRC Press 1999, p.1-14.

47. Menard KP. Dynamic Mechanical Analysis Basics: Part 2 Thermoplastic Transitions and Properties: Application note. Perkin Elmer Inc 2007.

48. Vojdani M, Giti R. Polyamide as a denture base material: A literature review. J Dent Shiraz Univ Med Sci 2015;16:1-9.

49. http://www.dl.com.tr/downloads/msds/deflex/DEFLEX_MSDS. pdf.

50. https://patentimages.storage.googleapis.com/15/ c7/2a/9ba9e36e51977c/US5266655.pdf. 